J. Dairy Sci. 92:3233-3243

doi:10.3168/jds.2008-1595

(c) American Dairy Science Association, 2009.

\title{
Differences in splanchnic metabolism between late gestation and early lactation dairy cows
}

\author{
L. Doepel, ${ }^{* 1}$ G. E. Lobley,† J. F. Bernier, $\ddagger$ P. Dubreuil, $\S$ and H. Lapierre\# ${ }^{2}$ \\ ${ }^{*}$ Department of Agricultural, Food and Nutritional Science, University of Alberta, Edmonton, AB, Canada T6G 2P5 \\ †Rowett Institute of Nutrition and Health, Aberdeen University, Aberdeen, United Kingdom AB21 9SB \\ ‡Département des Sciences Animales, Université Laval, Québec, QC, Canada G1V 0A6 \\ §Faculté de Médecine Vétérinaire, Université de Montréal, St-Hyacinthe, QC, Canada J2S 7C6 \\ \#Dairy and Swine Research and Development Centre, Agriculture and Agri-Food Canada, STN Lennoxville, Sherbrooke, QC, Canada J1M 1 Z3
}

ABSTRACT

In the transition from the pre- to postcalving state, the demands on the cow increase from support of gestation to high rates of milk production. This extra demand is met partly by increased intake but may also involve altered metabolism of major nutrients. Six multiparous Holstein cows were used to monitor changes in net fluxes of nutrients across the portal-drained viscera and liver (splanchnic tissues) between late gestation and early lactation. Blood samples were obtained simultaneously from the portal, hepatic, and subcutaneous abdominal veins and the caudal aorta $18 \mathrm{~d}$ before expected calving and 21 or $42 \mathrm{~d}$ after calving. On the day of blood sampling and the $3 \mathrm{~d}$ preceding sampling, cows were fed every $2 \mathrm{~h}$. The precalving (1.63 Mcal of net energy for lactation $/ \mathrm{kg}$ and $1,326 \mathrm{~g}$ of metabolizable protein/d) and postcalving (1.72 Mcal of net energy for lactation/ $\mathrm{kg}$ and 2,136 $\mathrm{g}$ of metabolizable protein/d) diets were based on corn silage, alfalfa hay, and corn grain. Dry matter intake increased postcalving. Net splanchnic release of glucose increased postpartum because of tendencies for both increased portal absorption and net liver release. Increased removal of lactate, rather than AA, contributed to the additional hepatic gluconeogenesis. Although portal absorption of AA increased with intake at the onset of lactation, hepatic removal of total AA-N tended to decline. This clearly indicates that liver removal of AA is not linked to portal absorption. Furthermore, net liver removal relative to total liver inflow even decreased for Gly, His, Met, Phe, and Tyr. Together, these data indicate that in early lactation, metabolic priority is given to direct AA toward milk protein production rather than gluconeogenesis, in cows fed a corn-based ration.

Received July 30, 2008.

Accepted March 9, 2009.

${ }^{1}$ Current address: University of Calgary, Faculty of Veterinary Medicine, AB, Canada T2N 4N1.

${ }^{2}$ Corresponding author: Helene.Lapierre@agr.gc.ca
Key words: splanchnic, amino acid, glucose, dairy cow

\section{INTRODUCTION}

Nutritional management and metabolism of the transition dairy cow have been extensively studied in recent years (see reviews by Drackley, 1999, and Overton and Waldron, 2004). It is widely recognized that intake in the immediate postpartum period lags behind that needed to support milk production such that the cow experiences negative energy and protein balance for several weeks following the initiation of lactation. To cope with the large increase in nutrient demand associated with milk production during this time, the cow experiences a multitude of metabolic adaptations (Bell, 1995).

At the initiation of lactation, the demand for glucose for lactose production increases markedly and is partially met by an increase in gluconeogenesis, as well as a decrease in glucose oxidation (Bennink et al., 1972; Bell, 1995). The contribution of AA to gluconeogenesis has been considered important during early lactation in the dairy cow (Bell, 1995), but supportive evidence has come from observations either ex vivo or in vitro (Overton et al., 1999; Drackley et al., 2001). The other important demand for AA is to support milk protein synthesis and this requirement increases greatly at the onset of lactation. Therefore, despite an increased supply of MP through increased DMI and rations formulated for lactation, these 2 demands create a negative protein balance for cows in early lactation.

Few studies have examined in vivo the hepatic removal of glucose precursors in relation to glucose net release by the liver in dairy cows in transition. Reynolds et al. (2003) reported net fluxes of several nutrients from 19 $\mathrm{d}$ before to $83 \mathrm{~d}$ after calving. Those authors concluded that there were minimal changes in splanchnic metabolism during the prepartum period, but that in early lactation there were substantial increases in liver net release of glucose concomitant with increased hepatic 
removal of propionate, lactate, glycerol, and alanine compared with that observed $19 \mathrm{~d}$ precalving The only AA measured was alanine, but the contribution of AA to liver glucose synthesis was estimated by difference between hepatic removal of other glucose precursors and glucose release. These estimates suggested that although the absolute amount of AA used to support gluconeogenesis was increased, the proportion of glucose derived from AA remained unchanged, except for alanine on d 11 postcalving.

Although it has been observed that circulating AA concentrations decrease in dairy cows in early lactation (Meijer et al., 1995; Doepel et al., 2002), it is not known to what extent this decrease is due to the pressure on available AA to support gluconeogenesis, milk protein production, or both. Recent studies, however, have shown that when protein supply is limited in dairy cows, the liver significantly reduces removal of most AA (Raggio et al., 2004), indicating a fundamental need to preserve AA to support milk protein output.

Therefore, we hypothesized that the metabolic priority of the dairy cow would direct AA toward milk protein synthesis rather than gluconeogenesis. Therefore, despite an increased absorption of AA, liver removal of AA would not increase in early lactation and the contribution of AA to glucose net release across the liver would not increase relative to late gestation. The objective of the current study was to examine the change in portal and liver net fluxes of AA, glucose, and lactate from late gestation to early lactation.

\section{MATERIALS AND METHODS}

\section{Animals and Treatments}

All experimental procedures were approved by the Institutional Committee for Animal Care of the Lennoxville Research Centre and animals were cared for in accordance with the guidelines of the Canadian Council on Animal Care (1993). At a minimum of 6 wk before calving, 8 multiparous Holstein cows were surgically implanted with abomasal catheters and chronic indwelling catheters in the mesenteric, portal, and hepatic veins and the caudal aorta via a mesenteric artery as described previously (Huntington et al., 1989; Doepel et al., 2006). In addition, the right carotid artery was surgically raised to a subcutaneous position to allow access to arterial blood in the event that the aorta catheter failed. Before calving, cows all received the same close-up diet and no abomasal infusion. The current comparisons form part of a larger study in which cows received abomasal infusions immediately after calving of either water or $300 \mathrm{~g} / \mathrm{d}$ glutamine in a crossover design with 21-d periods (Doepel et al., 2007). To avoid the confounding effects of the glutamine treatment (Doepel et al., 2007), only the data from the water treatments were used for the current comparison; that is, data were obtained either at d $21(\mathrm{n}=2)$ or d $42(\mathrm{n}=4)$ postcalving. Preliminary statistical analysis revealed that there were minimal differences in metabolic parameters between these 2 days and, therefore, data postcalving were aggregated as one time. Initially, treatment distribution was equal between the two 21 -d periods, but one cow calved before the precalving blood samples could be obtained, and one cow developed mastitis shortly after calving. Overall, cows were sampled $18 \pm 8 \mathrm{~d}$ precalving and $36 \pm 11 \mathrm{~d}$ postcalving and $\mathrm{n}=6$ for all data reported.

For 4 wk precalving and 6 wk postcalving, cows were fed diets as outlined in Doepel et al. (2006). Briefly, the precalving TMR contained 1.63 Mcal of $\mathrm{NE}_{\mathrm{L}} / \mathrm{kg}$ and supplied 1,326 $\mathrm{g}$ of $\mathrm{MP} / \mathrm{d}(14.1 \% \mathrm{CP})$, whereas the postcalving TMR contained $1.72 \mathrm{Mcal}$ of $\mathrm{NE}_{\mathrm{L}} / \mathrm{kg}$ and supplied 2,136 g of MP/d (16.8\% CP). Both TMR were based on corn silage, alfalfa hay, and corn grain. The precalving diet was fed ad libitum twice daily at 0800 and $1600 \mathrm{~h}$ except for d 18 to 21 before expected calving, when it was offered in 12 equal meals per day by automatic feeders. The postcalving diet was also offered ad libitum twice daily except for d 18 to 21 of each period, when it was supplied 12 times daily. Orts were recorded daily. Moisture content of the silages was determined weekly and used to make ration adjustments. Cows were milked twice daily at 0830 and 1930 $\mathrm{h}$, and milk yield was recorded at each milking. Milk was sampled at each milking from d 19 to 21 of each period.

\section{Blood Sampling}

On d $18(\mathrm{n}=6)$ precalving and $\mathrm{d} 21(\mathrm{n}=2)$ or $\mathrm{d}$ $42(\mathrm{n}=4)$ postcalving, blood samples were simultaneously collected into heparinized tubes from the arterial, hepatic venous, and portal catheters every $45 \mathrm{~min}$ for $4 \mathrm{~h}$ (6 samples), covering 2 cycles of feeding. In the postcalving periods, blood samples were also obtained by venipuncture from the subcutaneous abdominal vein following the same 45 -min sampling schedule. To determine plasma flow across the splanchnic tissues, para-amino hippuric acid (pAH; $10 \%$ wt/vol) was infused into a mesenteric vein catheter (Huntington et al., 1989). A priming dose of $2 \mathrm{~g}$ was given a minimum of $40 \mathrm{~min}$ before the first blood sample was obtained, followed by a continuous infusion of $14.4 \mathrm{~g} / \mathrm{h}$. Blood was placed on ice immediately after collection. All laboratory analyses were conducted on individual samples (i.e., samples were not pooled). Packed cell volume was determined by the microhematocrit method. For 
lactate analyses, $1 \mathrm{~mL}$ of fresh blood was mixed with $0.9 \mathrm{~mL}$ of water and $0.1 \mathrm{~mL}$ of $6 \mathrm{~N}$ perchloric acid and left on ice for $1 \mathrm{~h}$ before centrifugation and collection of the supernatant. The remainder of the blood was centrifuged $\left(15 \mathrm{~min}, 1,800 \times g\right.$ at $\left.4^{\circ} \mathrm{C}\right)$ within $30 \mathrm{~min}$ of collection. Urea-N and pAH were analyzed on fresh plasma samples. For AA analysis, $1 \mathrm{~g}$ of plasma was added to $0.2 \mathrm{~g}$ of an internal standard of AA labeled with stable isotopes and the processed samples frozen at $-80^{\circ} \mathrm{C}$. The internal standard solution was prepared with labeled AA diluted in water as outlined in Doepel et al. (2007). The labeled AA (95 to 99 atom \%) were supplied by CDN isotopes (Montreal, QC, Canada) for His, Leu, Lys, Met, and Phe, and by Cambridge Isotope Lab (Andover, MA) for others. The remainder of the plasma was stored at $-20^{\circ} \mathrm{C}$ for subsequent analysis of glucose and ammonia. Additional samples of arterial, portal, hepatic, and mammary blood $(2 \mathrm{~mL})$ were collected into a blood-gas collection device (Monovette, Sarstedt, Aktiegesellschaft and Co., Germany) for the determination of $\mathrm{pH}$ and partial pressure of oxygen.

\section{Laboratory Analyses}

Milk nitrogen content $(\mathrm{CP}=\mathrm{N} \times 6.38)$ was determined by combustion (Nitrogen Determinator, model FP-428, Leco, St. Joseph, MI). Milk true protein, whey, NPN, and casein contents were determined as described by Raggio et al. (2004). Phenylalanine and Tyr concentrations in milk were measured by the isotopic dilution method (Calder et al., 1999) after hydrolysis as described by Borucki Castro et al. (2007). Milk fat was measured according to the Röse-Gottlieb method (AOAC, 1996), whereas milk lactose was calculated as milk DM $\%$ - (fat $\%+$ protein $\%+$ ash $\%$ ).

Partial pressure of oxygen $\left(\mathrm{O}_{2}\right)$ and $\mathrm{pH}$ were determined in fresh blood using a blood gas analyzer (model IL 1306, Instrument Laboratory, Lexington, MA). A spectrophotometric method using lactate dehydrogenase was used to measure blood L-lactate concentration (Benson et al., 2002). Blood hemoglobin was determined colorimetrically using cyanmethemoglobin as the standard. Plasma concentrations of urea- $\mathrm{N}$ and $\mathrm{pAH}$ were determined on the day of sampling with an automatic analyzer (Technicon Autoanalyser II, Technicon Instruments Corp., Tarrytown, NY) as described previously (Eisemann et al., 1987). An enzymatic reaction (glutamate dehydrogenase) as described by Bergmeyer and Beutler (1985) was used to determine ammonia concentrations no more than $1 \mathrm{wk}$ after blood sampling. Glucose concentrations were determined colorimetrically using an enzymatic (glucose oxidase/peroxidase) reaction (Boehringer Mannheim, Dorval, QC, Canada).
Plasma amino acid concentrations were measured by isotope dilution using GC-MS (Calder et al., 1999).

\section{Calculations}

Milk AA output in protein was calculated using crude milk protein yield measured during the last $3 \mathrm{~d}$ of each period, with a $3.5 \%$ correction for bloodborne proteins, and reported AA composition (Swaisgood, 1995), with the exception of Phe and Tyr, which were analyzed. Mammary plasma flow was estimated according to the Fick principle using Phe and Tyr as internal markers, again with allowance for a $3.5 \%$ contribution from bloodborne proteins: mammary plasma flow $=($ milk $[$ Phe + Tyr $] \times 0.965) \div($ arterial - mammary $[$ Phe + Tyr]), as described by Cant et al. (1993). Plasma flow across the splanchnic tissues was calculated from downstream dilution of the infused pAH (Katz and Bergman, 1969). The net fluxes of AA and glucose across the portal-drained viscera (PDV), liver, total splanchnic tissues (TSP), and mammary gland were calculated as the product of the average plasma venous-arterial concentration difference and the average plasma flow. Ammonia and lactate net fluxes were calculated using plasma and blood concentrations, respectively, and blood flow. Blood flow was calculated as plasma flow divided by (1 - packed cell volume). Urea fluxes were calculated using plasma water concentrations [plasma concentration $/(1-\mathrm{DM}$ of plasma $)]$ and blood water flows, which were calculated as blood flow multiplied by (1 - DM of blood) (Milano et al., 2000). A negative flux indicates utilization or removal, whereas a positive flux indicates net production or release of the nutrient across the tissue. Concentrations of $\mathrm{O}_{2}$ in blood were calculated using measured partial pressure of $\mathrm{O}_{2}, \mathrm{pH}$, and hemoglobin concentration (Bartels and Harms, 1959). Hepatic removal of AA as a percentage of PDV release was calculated as hepatic net flux/portal net flux $\times 100$. Hepatic extraction as a percentage of total supply was calculated as hepatic net flux/liver total inflow $\times 100$, with total inflow calculated as the product of portal concentration and portal plasma flow plus the product of hepatic arterial plasma flow and arterial concentration.

\section{Statistical Analysis}

Metabolite concentrations and net flux data were averaged over the 6 sampling times on each sampling day for statistical analysis. Dry matter intake, milk yield, and milk composition were averaged over the last $3 \mathrm{~d}$ of each period. All data were statistically analyzed using the GLM procedure (SAS Institute, 1999) with time 
Table 1. Dry matter intake and milk production during the pre- and postcalving periods

\begin{tabular}{lcccc}
\hline & \multicolumn{2}{c}{ Time } & & \\
\cline { 2 - 3 } Item & Precalving & Postcalving & SEM/SD & P-value \\
\hline DMI, kg/d & 14.7 & 18.5 & 0.44 & 0.002 \\
Yield & & 40.2 & 5.4 & \\
Milk, kg/d & 1,214 & 152 & \\
CP, g/d & 1,161 & 144 & \\
True protein, g/d & 1,001 & 101 & \\
Casein, g/d & 159 & 46 & \\
Whey, g/d & 1,493 & 224 & \\
Fat, g/d & 1,876 & 224 & \\
Lactose, g/d & & & \\
Milk composition & 3.03 & 0.13 & \\
CP, \% & 95.6 & 0.6 & \\
True protein, \% of CP & 82.7 & 2.7 \\
Casein, \% of CP & 12.9 & 2.5 \\
Whey, \% of CP & 3.71 & 0.19 \\
Fat, \% & 4.69 & 0.34 & \\
Lactose, \% & & & \\
\hline
\end{tabular}

${ }^{1} \mathrm{DMI}$ reported as least squares means $\pm \mathrm{SEM}$; all other data reported as means $\pm \mathrm{SD} ; \mathrm{n}=6$.

(precalving vs. postcalving) as the main effect and cow as a blocking factor. Differences were considered significant if $P \leq 0.10$ and as a trend for $0.10<P \leq 0.15$. Data are reported as least squares means with pooled standard errors (SEM), unless otherwise stated.

\section{RESULTS AND DISCUSSION}

\section{DMI and Plasma Flow}

The exact time of sampling averaged $18.3 \pm 8.4 \mathrm{~d}$ before calving and $36.3 \pm 11.2$ after calving. Milk yield and DMI are shown in Table 1. Dry matter intake increased by $3.8 \mathrm{~kg} / \mathrm{d}$ from d 18 precalving to d 36 postcalving. The intake at d 36 is typical for this period (Doepel et al., 2002; Reynolds et al., 2003), whereas the precalving intake is higher than that reported by Reynolds et al. (2003) but similar to that observed by Doepel et al. (2002). This difference in precalving intake between the 2 studies may be related to the high NDF content and composition (high lignin due to straw inclusion) of the diet used by Reynolds et al. (2003), which may have limited intake as a result of slow passage rate through the rumen.

Portal plasma flow increased from $1,119 \mathrm{~L} / \mathrm{h}$ precalving to $1,522 \mathrm{~L} / \mathrm{h}$ postcalving (SEM: $74.8, P=0.01$ ), whereas hepatic flow increased from 1,323 to 1,896 L/h (SEM: 96.4, $P=0.02$ ). Likewise, portal and hepatic blood flows, calculated using packed cell volumes of 29.1 and $28.4 \%$ pre- and postcalving, respectively, also increased. Reynolds et al. (2003) reported portal plasma flows of $695 \mathrm{~L} / \mathrm{h}$ at $19 \mathrm{~d}$ precalving and 1,340 $\mathrm{L} / \mathrm{h}$ at $33 \mathrm{~d}$ postcalving. This equates to a $93 \%$ increase pre- to postcalving, whereas in the current study the increase was $36 \%$. This discrepancy probably relates to differences in energy intake between the 2 studies, as positive correlations between blood flow and energy intake have been reported (Huntington, 1990; Lescoat et al., 1996). In the current study, precalving ME intake was $37.8 \mathrm{Mcal} / \mathrm{d}$ and increased to $49.2 \mathrm{Mcal} / \mathrm{d}$ (a $30 \%$ increase), whereas in the study of Reynolds et al. (2003) ME intake increased $150 \%$ from $22.5 \mathrm{Mcal} / \mathrm{d}$ precalving to $56.2 \mathrm{Mcal} / \mathrm{d}$ postcalving.

\section{Net Fluxes of Nitrogen Compounds}

$\boldsymbol{A} \boldsymbol{A}$. Arterial concentrations of all AA decreased ( $P$ $<0.05)$ with the onset of lactation with the exception of the branched-chain AA, Ala, Thr, and Trp, which were not affected $(P>0.15)$, and Gly, which increased $(P=0.02$; Table 2$)$. This decrease in AA concentrations occurred despite the increase in both MP supply and net portal absorption of AA $(P<0.07)$ in early lactation versus late gestation cows (Table 3). Only Cys and Gln net portal absorptions were not affected by time before or after parturition, but net portal absorption of these AA is relatively small. Despite this increased net absorption of $\mathrm{AA}$, net liver removal did not increase for most AA. Net liver flux of Ala, Cys, Glu, Ile, Leu, Met, Ser, Thr, and Val was not affected by physiological state (i.e., gestation vs. lactation), whereas liver net removal of Gln, His, Lys, and Tyr decreased $(P<0.10)$ or tended to decrease $(P=0.12)$ for Phe. Only net liver removal of Gly and Trp increased $(P<0.05)$.

These observations raise several issues. First, it has been suggested that liver removal of AA is related to net portal supply (Lescoat et al., 1996). In practice, increased AA portal absorption is usually associated with 
Table 2. Arterial concentrations of amino acids $(\mu M)$ in Holstein cows pre- and postcalving ${ }^{1}$

\begin{tabular}{|c|c|c|c|c|}
\hline Amino acid & Precalving & Postcalving & SEM & $P$-value \\
\hline Ala & 221.8 & 194.0 & 13.8 & 0.21 \\
\hline Cys & 130.7 & 96.2 & 4.7 & 0.003 \\
\hline Gln & 311.0 & 216.7 & 14.8 & 0.006 \\
\hline Glu & 68.7 & 50.4 & 3.6 & 0.02 \\
\hline Gly & 194.5 & 319.1 & 25.5 & 0.02 \\
\hline His & 71.3 & 52.3 & 3.8 & 0.02 \\
\hline Ile & 149.0 & 180.1 & 17.0 & 0.25 \\
\hline Leu & 215.4 & 175.9 & 18.2 & 0.19 \\
\hline Lys & 99.0 & 74.8 & 5.3 & 0.02 \\
\hline Met & 26.6 & 22.1 & 1.0 & 0.03 \\
\hline Phe & 58.0 & 43.3 & 2.1 & 0.004 \\
\hline Ser & 79.1 & 62.5 & 3.7 & 0.03 \\
\hline Thr & 93.0 & 80.1 & 6.1 & 0.20 \\
\hline Trp & 47.3 & 48.5 & 1.6 & 0.62 \\
\hline Tyr & 64.4 & 44.0 & 1.3 & 0.0001 \\
\hline Val & 277.2 & 269.8 & 26.0 & 0.85 \\
\hline TAA-N ${ }^{2}$ & 2,695 & 2,353 & 124 & 0.11 \\
\hline TEAA-N ${ }^{2}$ & 1,312 & 1,166 & 73 & 0.22 \\
\hline TNEAA-N $^{2}$ & 1,382 & 1,195 & 61 & 0.08 \\
\hline Group $1 \mathrm{AA}-\mathrm{N}^{2}$ & 535.1 & 426.7 & 20.1 & 0.01 \\
\hline Group 2 AA-N ${ }^{2}$ & 839.1 & 779.1 & 64.0 & 0.54 \\
\hline
\end{tabular}

greater plasma concentrations and in such situations, we cannot determine if either or both are regulating factors of hepatic removal. However, when AA supply was increased via jugular infusion resulting in increased concentrations but with no change in portal absorption, the relationship between hepatic removal and net portal absorption no longer existed (Berthiaume et al., 2002). Similarly, dissociation between these 2 parameters has been established under the more physiological experimental conditions in the current study: lactation increased intake and, thus, net portal absorption of AA, whereas the high demand to support milk protein secretion led to reduced concentrations of AA. These 2 experimental approaches lead to the same conclusion, however, that net liver removal is not driven by net portal absorption. Rather, in the current study, the ratio of liver removal to net absorption even decreased $(P$ $<0.10$ ) when net portal absorption increased between late gestation and early lactation for all AA except Cys, Gly, Thr, and Trp (Table 4). It has been suggested that liver removal may be better correlated with total inflow rather than with portal absorption (Lobley and Lapierre, 2003; Hanigan, 2005; Lapierre et al., 2005 ), because total inflow involves integration of both portal absorption and utilization by peripheral tissues. Such a concept implies that hepatic extraction is not exclusively due to first-pass removal but rather that a constant fraction of the total liver inflow is extracted per pass, with the amount returned to the liver driven by peripheral tissue utilization. Higher rates of removal by peripheral tissues such as the mammary gland return a smaller quantity of AA to the liver where less is then extracted and catabolized. In the current study, although the physiological state of the cow had a lesser effect on the ratio of net liver removal to total inflow than when expressed relative to portal absorption, the fraction of liver removal relative to total inflow for Gly, His, Phe, and Tyr decreased $(P<0.10)$ postcalving compared with precalving and tended to decrease $(P=$ 0.11 ) for Met. This indicates that fractional extraction by the liver varies with physiological state.

This hypothesis further predicts that the liver would remove AA not utilized for milk protein production. The impact of such a mechanism would be enhanced if there was a concomitant reduction in utilization of AA by the liver, for either energy (oxidative) or anabolic (e.g., gluconeogenesis) purposes. Although such regulation is not fully defined, how the AA are partitioned between the liver for gluconeogenic purposes will depend on a combination of nutritional, physiological, and genetic factors, and aspects of these will be discussed later in association with glucose net flux. Indeed, changes in hormone concentrations and sensitivity occurring at the onset of lactation (Kunz et al., 1985; Gerloff et al., 1986; VandeHaar et al., 1999) may contribute to the differences in hepatic metabolism observed between gestating and lactating cows. For example, growth hormone is elevated at the initiation of lactation (Ko- 
DOEPEL ET AL.

Table 3. Splanchnic and mammary net fluxes of amino acids $(\mathrm{mmol} / \mathrm{h})$ in Holstein cows pre- and postcalving $^{1}$

\begin{tabular}{|c|c|c|c|c|c|}
\hline Amino acid & Tissue $^{2}$ & Precalving & Postcalving & $\mathrm{SEM}^{3}$ & $P$-value \\
\hline \multirow[t]{5}{*}{ Ala } & PDV & 60.5 & 83.2 & 4.2 & 0.01 \\
\hline & Liver & -59.4 & -62.0 & 4.9 & 0.72 \\
\hline & TSP & $1.1^{*}$ & 21.2 & 1.4 & 0.0002 \\
\hline & MG & & -31.8 & (10.4) & - \\
\hline & Milk & & 18.1 & $(2.3)$ & - \\
\hline \multirow[t]{5}{*}{ Cys } & PDV & $2.9^{*}$ & 4.3 & 1.7 & 0.58 \\
\hline & Liver & $-2.7 \dagger$ & -5.2 & 1.3 & 0.23 \\
\hline & TSP & $0.2^{*}$ & $-0.9^{*}$ & 0.5 & 0.20 \\
\hline & MG & & -5.6 & $(5.4)$ & - \\
\hline & Milk & & 2.8 & $(0.4)$ & - \\
\hline \multirow[t]{5}{*}{ Gln } & PDV & $3.8^{*}$ & $4.2^{*}$ & 4.6 & 0.95 \\
\hline & Liver & -31.0 & $4.8^{*}$ & 5.9 & 0.008 \\
\hline & TSP & -27.3 & $9.0 \dagger$ & 4.0 & 0.001 \\
\hline & MG & & -26.1 & $(17.1)$ & - \\
\hline & Milk & & 31.4 & (3.9) & - \\
\hline \multirow{5}{*}{ Glu } & PDV & $-0.8^{*}$ & 10.7 & 1.9 & 0.008 \\
\hline & Liver & 36.2 & 30.6 & 5.2 & 0.48 \\
\hline & TSP & 35.4 & 41.3 & 5.1 & 0.45 \\
\hline & MG & & -21.8 & $(4.6)$ & - \\
\hline & Milk & & 40.1 & $(5.0)$ & - \\
\hline \multirow[t]{5}{*}{ Gly } & PDV & 25.8 & 44.0 & 2.3 & 0.003 \\
\hline & Liver & -38.4 & -62.5 & 2.6 & 0.001 \\
\hline & TSP & -12.7 & -18.5 & 2.5 & 0.16 \\
\hline & MG & & -8.0 & (12.4) & - \\
\hline & Milk & & 11.7 & $(1.5)$ & - \\
\hline \multirow{5}{*}{ His } & PDV & 7.2 & 9.8 & 0.4 & 0.007 \\
\hline & Liver & -4.7 & -3.0 & 0.6 & 0.09 \\
\hline & TSP & 2.5 & 6.8 & 0.4 & 0.0006 \\
\hline & MG & & -10.0 & $(2.5)$ & - \\
\hline & Milk & & 8.5 & (1.1) & - \\
\hline \multirow[t]{5}{*}{ Ile } & PDV & 19.0 & 29.2 & 1.4 & 0.004 \\
\hline & Liver & $1.7^{*}$ & $2.5 \dagger$ & 1.3 & 0.64 \\
\hline & $\mathrm{TSP}$ & 20.6 & 31.8 & 2.2 & 0.02 \\
\hline & MG & & -26.5 & (3.6) & - \\
\hline & Milk & & 22.0 & (2.7) & - \\
\hline \multirow[t]{5}{*}{ Leu } & PDV & 31.8 & 45.2 & 2.2 & 0.008 \\
\hline & Liver & 3.9 & $2.6 \dagger$ & 1.1 & 0.45 \\
\hline & TSP & 35.7 & 47.8 & 2.8 & 0.03 \\
\hline & MG & & -39.4 & $(3.5)$ & - \\
\hline & Milk & & 36.5 & $(4.6)$ & - \\
\hline \multirow[t]{5}{*}{ Lys } & PDV & 29.2 & 37.1 & 1.7 & 0.02 \\
\hline & Liver & $-8.7^{*}$ & $5.2^{*}$ & 4.6 & 0.09 \\
\hline & TSP & 20.4 & 42.2 & 3.3 & 0.006 \\
\hline & MG & & -37.2 & $(7.9)$ & - \\
\hline & Milk & & 27.7 & $(3.5)$ & - \\
\hline \multirow[t]{5}{*}{ Met } & PDV & 8.0 & 14.8 & 2.1 & 0.07 \\
\hline & Liver & -4.9 & -4.7 & 0.9 & 0.92 \\
\hline & TSP & $3.2 \dagger$ & 10.1 & 1.3 & 0.01 \\
\hline & MG & & -8.8 & $(0.4)$ & - \\
\hline & Milk & & 9.2 & (1.1) & - \\
\hline \multirow[t]{5}{*}{ Phe } & PDV & 18.6 & 26.1 & 1.0 & 0.003 \\
\hline & Liver & -13.8 & -10.7 & 1.2 & 0.12 \\
\hline & TSP & 4.8 & 15.4 & 0.7 & 0.0001 \\
\hline & MG & & -15.2 & (1.8) & - \\
\hline & Milk & & 14.6 & (1.8) & - \\
\hline \multirow[t]{5}{*}{ Ser } & PDV & 29.7 & 42.2 & 0.8 & 0.0001 \\
\hline & Liver & -26.9 & -30.6 & 1.9 & 0.23 \\
\hline & TSP & $2.8 \dagger$ & 11.6 & 1.2 & 0.003 \\
\hline & MG & & -20.2 & $(4.5)$ & - \\
\hline & Milk & & 29.3 & $(3.7)$ & - \\
\hline \multirow[t]{5}{*}{ Thr } & PDV & 18.2 & 27.6 & 0.7 & 0.003 \\
\hline & Liver & -7.5 & -7.6 & 1.1 & 0.99 \\
\hline & TSP & 10.6 & 20.0 & 1.1 & 0.002 \\
\hline & MG & & -20.1 & $(3.0)$ & - \\
\hline & Milk & & 17.6 & $(2.2)$ & - \\
\hline
\end{tabular}


Table 3 (Continued). Splanchnic and mammary net fluxes of amino acids ( $\mathrm{mmol} / \mathrm{h})$ in Holstein cows preand postcalving ${ }^{1}$

\begin{tabular}{|c|c|c|c|c|c|}
\hline Amino acid & Tissue $^{2}$ & Precalving & Postcalving & $\mathrm{SEM}^{3}$ & $P$-value \\
\hline \multirow[t]{5}{*}{$\operatorname{Trp}$} & PDV & 3.7 & 7.6 & 0.9 & 0.04 \\
\hline & Liver & -1.7 & -3.6 & 0.5 & 0.05 \\
\hline & TSP & 2.1 & 4.0 & 0.5 & 0.04 \\
\hline & MG & & -5.0 & $(2.0)$ & - \\
\hline & Milk & & 3.6 & $(0.5)$ & - \\
\hline \multirow[t]{5}{*}{ Tyr } & PDV & 15.7 & 22.1 & 0.9 & 0.004 \\
\hline & Liver & -12.8 & -9.3 & 1.0 & 0.051 \\
\hline & TSP & 2.9 & 12.8 & 0.8 & 0.0004 \\
\hline & MG & & -13.8 & $(2.0)$ & - \\
\hline & Milk & & 14.3 & (1.8) & - \\
\hline \multirow[t]{5}{*}{ Val } & PDV & 20.2 & 33.6 & 1.1 & 0.0004 \\
\hline & Liver & $2.3^{*}$ & $1.5^{*}$ & 1.9 & 0.79 \\
\hline & TSP & 22.6 & 35.1 & 2.1 & 0.009 \\
\hline & MG & & -33.0 & $(5.0)$ & - \\
\hline & Milk & & 27.5 & $(3.4)$ & - \\
\hline \multirow[t]{5}{*}{ TAA-N ${ }^{4}$} & $\mathrm{PDV}$ & 317.5 & 524.0 & 19.6 & 0.0007 \\
\hline & Liver & -209.0 & -147.7 & 25.2 & 0.15 \\
\hline & TSP & 108.5 & 376.3 & 16.8 & $<0.0001$ \\
\hline & MG & & -401.5 & $(85.5)$ & - \\
\hline & Milk & & 394.5 & (49.3) & - \\
\hline \multirow[t]{5}{*}{ TEAA-N $^{4}$} & PDV & 187.0 & 310.0 & 11.3 & 0.0006 \\
\hline & Liver & -41.5 & -26.0 & 5.6 & 0.11 \\
\hline & TSP & 145.5 & 283.9 & 13.0 & 0.0007 \\
\hline & MG & & -252.4 & $(34.1)$ & - \\
\hline & Milk & & 215.4 & $(26.9)$ & - \\
\hline \multirow[t]{5}{*}{ TNEAA-N $^{4}$} & PDV & 139.9 & 208.5 & 15.5 & 0.03 \\
\hline & Liver & -170.0 & -129.2 & 21.0 & 0.23 \\
\hline & TSP & -30.0 & 79.3 & 7.0 & 0.0001 \\
\hline & MG & & -151.4 & $(55.3)$ & - \\
\hline & Milk & & 179.1 & $(22.4)$ & - \\
\hline \multirow[t]{5}{*}{ Group 1 AA-N ${ }^{4}$} & PDV & 82.7 & 138.9 & 5.1 & 0.0006 \\
\hline & Liver & -52.7 & -48.9 & 3.9 & 0.52 \\
\hline & TSP & 30.0 & 90.1 & 2.6 & $<0.0001$ \\
\hline & MG & & -94.8 & $(14.8)$ & - \\
\hline & Milk & & 88.4 & (11.0) & - \\
\hline \multirow{5}{*}{ Group 2 AA- $\mathrm{N}^{4}$} & PDV & 128.9 & 186.1 & 6.4 & 0.002 \\
\hline & Liver & $-9.5^{*}$ & $17.4 \dagger$ & 8.8 & 0.08 \\
\hline & TSP & 119.4 & 203.5 & 8.1 & 0.0007 \\
\hline & MG & & -172.8 & $(25.5)$ & - \\
\hline & Milk & & 141.3 & (17.7) & - \\
\hline
\end{tabular}

${ }^{1}$ Least squares means $\pm \mathrm{SEM} ; \mathrm{n}=6$.

${ }^{2} \mathrm{PDV}=$ portal-drained viscera $\mathrm{TSP}=$ total splanchnic tissue; $\mathrm{MG}=$ mammary gland.

${ }^{3}$ Values in parentheses are SD, not SEM.

${ }^{4}$ TAA-N = total AA-N; TEAA-N = total essential AA-N (His, Ile, Leu, Lys, Met, Phe, Thr, Trp, and Val); TNEAA-N = total nonessential AA-N (Ala, Cys, Gln, Glu, Gly, Ser, and Tyr); group 1 AA-N = His, Met, Phe, Tyr, and Trp; group 2 AA-N = Ile, Leu, Lys, and Val.

${ }^{*} P<0.05 ; \dagger P<0.10$ : not significantly different from zero.

prowski and Tucker, 1973) and induction of growth hormone release with growth hormone-releasing factor reduced liver removal of $\alpha$-amino $\mathrm{N}$ (Reynolds et al., 1992).

The TSP net flux of all AA increased $(P<0.05)$ with the onset of lactation and the associated increase in MP supply, except for Cys and Glu release that were not affected and for Gly, for which there was net splanchnic uptake (Table 3). Glycine is unusual as the only AA for which post-liver supply is usually negative, indicating elevated utilization by the liver for functions such as hippurate detoxification as well as glutathione synthesis. For the essential AA (EAA), post-liver supply always met or exceeded mammary uptake, except for His, although according to NRC (2001), these cows would be fed only $90 \%$ of MP requirements. The MP requirements are estimated using a fixed conversion factor of absorbed protein to metabolic functions of $67 \%$, but previous studies have shown that dairy cows at restricted intakes are more efficient in the transfer of absorbed AA into milk protein (Doepel et al., 2004; Raggio et al., 2004). The increase in efficiency under situations of limited supply is also supported, in part, by the current observations because no mobilization of 
Table 4. Net liver flux of amino acids as a percentage of net portal-drained visceral release or total liver inflow in Holstein cows pre- and postcalving ${ }^{1}$

\begin{tabular}{|c|c|c|c|c|c|}
\hline Amino acid & Parameter $^{2}$ & Precalving & Postcalving & SEM & $P$-value \\
\hline \multirow[t]{2}{*}{ Ala } & Removal & 96.5 & 74.0 & 5.6 & 0.04 \\
\hline & Extraction & 16.1 & 14.1 & 1.7 & 0.47 \\
\hline \multirow[t]{2}{*}{ Cys } & Removal & 87.8 & 152.2 & 18.4 & 0.06 \\
\hline & Extraction & 1.5 & 2.8 & 0.7 & 0.25 \\
\hline \multirow[t]{2}{*}{ Gly } & Removal & 348.8 & 144.2 & 147.2 & 0.37 \\
\hline & Extraction & 13.3 & 10.1 & 1.0 & 0.08 \\
\hline \multirow[t]{2}{*}{ His } & Removal & 58.2 & 27.2 & 4.7 & 0.005 \\
\hline & Extraction & 4.4 & 2.4 & 0.6 & 0.07 \\
\hline \multirow[t]{2}{*}{ Met } & Removal & 55.1 & 29.1 & 4.4 & 0.009 \\
\hline & Extraction & 10.6 & 7.6 & 1.0 & 0.11 \\
\hline \multirow[t]{2}{*}{ Phe } & Removal & 70.8 & 38.3 & 3.7 & 0.002 \\
\hline & Extraction & 13.8 & 9.3 & 0.7 & 0.008 \\
\hline \multirow[t]{2}{*}{ Ser } & Removal & 88.1 & 70.3 & 4.0 & 0.03 \\
\hline & Extraction & 19.3 & 19.3 & 1.2 & 0.97 \\
\hline \multirow[t]{2}{*}{ Thr } & Removal & 33.4 & 24.5 & 5.6 & 0.31 \\
\hline & Extraction & 4.8 & 3.8 & 0.8 & 0.40 \\
\hline \multirow[t]{2}{*}{ Trp } & Removal & 32.4 & 43.0 & 6.3 & 0.30 \\
\hline & Extraction & 2.2 & 3.4 & 0.8 & 0.35 \\
\hline \multirow[t]{2}{*}{ Tyr } & Removal & 79.8 & 37.9 & 7.3 & 0.008 \\
\hline & Extraction & 12.2 & 7.9 & 0.9 & 0.02 \\
\hline \multirow[t]{2}{*}{ TAA-N ${ }^{3}$} & Removal & 58.5 & 24.0 & 4.9 & 0.004 \\
\hline & Extraction & 4.9 & 2.7 & 0.7 & 0.06 \\
\hline \multirow[t]{2}{*}{ TEAA-N ${ }^{3}$} & Removal & 14.5 & 4.8 & 6.6 & 0.34 \\
\hline & Extraction & 1.6 & 0.7 & 0.5 & 0.21 \\
\hline \multirow[t]{2}{*}{ TNEAA-N ${ }^{3}$} & Removal & 138.8 & 56.4 & 17.2 & 0.02 \\
\hline & Extraction & 8.3 & 5.2 & 1.0 & 0.07 \\
\hline \multirow{2}{*}{ Group 1 AA-N ${ }^{3}$} & Removal & 60.4 & 30.6 & 4.2 & 0.004 \\
\hline & Extraction & 6.3 & 4.6 & 0.7 & 0.14 \\
\hline
\end{tabular}

${ }^{1}$ Least squares means $\pm \mathrm{SEM} ; \mathrm{n}=6$.

${ }^{2}$ Removal $=$ hepatic net flux/portal net flux $\times 100$; extraction $=($ hepatic net flux/liver total inflow $) \times 100$.

${ }^{3}$ TAA-N = total AA-N; TEAA-N = total essential AA-N (His, Ile, Leu, Lys, Met, Phe, Thr, Trp, and Val);

TNEAA-N = total nonessential AA-N (Ala, Cys, Gln, Glu, Gly, Ser, and Tyr); group 1 AA-N = His, Met,

Phe, Tyr, and Trp.

Table 5. Metabolite and oxygen arterial concentrations $(\mathrm{m} M)$ and net fluxes $(\mathrm{mmol} / \mathrm{h})$ in Holstein cows pre- and postcalving ${ }^{1}$

\begin{tabular}{|c|c|c|c|c|c|c|}
\hline Metabolite & & Tissue $^{2}$ & \multicolumn{2}{|c|}{ Treatment } & $\mathrm{SEM}^{3}$ & $P$-value \\
\hline \multirow[t]{4}{*}{ Glucose } & Concentration & & 3.63 & 2.87 & 0.09 & 0.002 \\
\hline & & Liver & 521 & 669 & 58.2 & 0.15 \\
\hline & & TSP & 487 & 703 & 33.4 & 0.01 \\
\hline & & MG & & -590 & $(52)$ & \\
\hline & & Liver & -110 & -287 & 21.8 & 0.002 \\
\hline & & TSP & -45 & -121 & 26.9 & 0.10 \\
\hline \multirow[t]{4}{*}{ Oxygen } & Concentration & & 6.13 & 5.74 & 0.18 & $<0.0001$ \\
\hline & Flux & PDV & $-2,328$ & $-2,970$ & 108 & 0.01 \\
\hline & & Liver & $-3,002$ & $-4,346$ & 450 & 0.09 \\
\hline & & TSP & $-5,326$ & $-7,351$ & 437 & 0.02 \\
\hline Ammonia & Concentration & & 0.060 & 0.041 & 0.017 & 0.46 \\
\hline & & Liver & 808 & 1,100 & 99.3 & 0.09 \\
\hline & & TSP & 406 & 656 & 87.9 & 0.10 \\
\hline
\end{tabular}

${ }^{1}$ Least squares means $\pm \mathrm{SEM} ; \mathrm{n}=6$; negative values indicate net removal, whereas positive values indicate net release across the tissue. ${ }^{2} \mathrm{PDV}=$ portal-drained viscera; $\mathrm{TSP}=$ total splanchnic tissues; $\mathrm{MG}=$ mammary gland.

${ }^{3}$ Values in parentheses are standard deviation, not SEM. 
body proteins was required to provide sufficient postliver supply of EAA to account for mammary uptake, although MP supply was less than predicted requirements (NRC, 2001). The net portal absorption and post-liver supply of the EAA were both in excess of mammary gland uptake and the amounts secreted in milk protein (Table 3), a comparative approach that has been validated in several recent studies (see Lapierre et al., 2005). The exception was His, but this AA can be supplied, without degrading tissue protein, from stores such as the intra-muscle dipeptide carnosine (not measured in this study) or from hemoglobin, as suggested for His-deficient pigs (Heger et al., 2007). In the current study, hemoglobin concentrations decreased numerically from 10.5 to $9.8 \pm 0.3 \mathrm{~g} / 100 \mathrm{~mL}$ from late gestation to lactation, and that could account for an endogenous supply of His of $0.5 \mathrm{mmol} / \mathrm{h}$.

Regarding the nonessential AA (NEAA), the deficit in NEAA-N at the mammary gland (Clark et al., 1977; Guinard and Rulquin, 1994) is usually met by surplus extraction of the EAA, especially those of group 2 (Ile, Leu, Lys, and Val), allowing $\mathrm{N}$ balance to be attained (Raggio et al., 2006). Similarly, in the current study with cows in early lactation, mammary uptake relative to milk output was in excess for EAA-N (252 vs. 215 $\mathrm{mmol} / \mathrm{h}$ ), whereas uptake of NEAA-N was in deficit (152 vs. $179 \mathrm{mmol} / \mathrm{h})$.

Ammonia and Urea. Arterial plasma ammonia concentrations were not different $(P=0.46)$ between the pre- and postcalving periods (Table 5). Although PDV ammonia absorption was higher postpartum than prepartum $(P=0.03)$, liver uptake was also higher $(P$ $=0.07)$ resulting in no net difference in post-hepatic release. The postpartum increase in portal absorption is related to the higher dietary $\mathrm{CP}$ intake during this time ( $3,145 \mathrm{~g} / \mathrm{d}$ postpartum vs. $2,058 \mathrm{~g} / \mathrm{d}$ prepartum). Net flux of urea-N across the PDV was negative, averaging $423 \mathrm{mmol} / \mathrm{h}$ across both periods, and is representative of urea recycling through the gut wall. The increased $(P=0.07)$ plasma concentrations of urea- $\mathrm{N}$ in the postpartum period resulted from elevated hepatic ureagenesis $(P=0.09)$, with increased hepatic removal of ammonia accounting for most of the increased urea net release.

\section{Net Fluxes of Energy Metabolites}

Glucose. Total post-liver supply of glucose was 216 $\mathrm{mmol} / \mathrm{h}$ higher in early lactation compared with late gestation $(P=0.01$, Table 5$)$, with approximately $30 \%$ of this increase resulting from increased net portal flux (shift from utilization to absorption) and $70 \%$ from hepatic gluconeogenesis. The difference between pre- and postcalving hepatic glucose output reported by Reynolds et al. (2003) was larger than that observed in the current study. Their precalving diet, however, supplied less ME than in the current study, and glucose rate of appearance is thought to be closely linked to digestible energy intake in cattle (Wieghart et al., 1986). Postcalving, TSP glucose supply was $703 \mathrm{mmol} / \mathrm{h}$, more than the requirement of $588 \mathrm{mmol} / \mathrm{h}$ estimated by Overton (1998) but close to the $737 \mathrm{mmol} / \mathrm{h}$ predicted by Danfaer et al. (1995) for lactating cows. The proportion of glucose net splanchnic release required to support lactose synthesis (457 mmol/h) averaged 68\%. Lemosquet et al. (2007) reported that lactose synthesis averaged $73 \%$ of glucose rate of appearance, which would include, in addition to net splanchnic release of glucose, kidney synthesis of glucose and glycogenolysis. The increase in glucose net flux across the TSP during the transition from gestation to early lactation, however, was only half of that required to cover milk lactose output. This would imply that glucose utilization for other metabolic pathways is altered by lactation. Indeed, glucose oxidation has been reported to decrease at the onset of lactation (Benninck et al., 1972) and, similarly, administration of growth hormone increased lactose output and decreased glucose oxidation (Bauman et al., 1988).

It has been proposed that the contribution of AA to hepatic gluconeogenesis increases at the initiation of lactation in both proportional (Drackley et al., 2001) and absolute (Reynolds et al., 2003) terms. For example, Reynolds et al. (2003) estimated that the minimum contribution of AA to gluconeogenesis did not vary between $\mathrm{d}-19$ to $\mathrm{d}+83$ of calving and averaged $23 \%$. As glucose production increased from 294 to $840 \mathrm{mmol} / \mathrm{h}$ over that period, this would lead to an increased net liver removal of AA (from $\sim 60$ to $200 \mathrm{mmol}$ glucose equivalents per $\mathrm{h}$ ). However, for the only AA measured, net removal of Ala was higher at d 11 and 21 but not at d 33 and 83 postcalving compared with precalving values. Therefore, the contribution of alanine to gluconeogenesis more than doubled from $9 \mathrm{~d}$ before calving $(2.3 \%)$ to $11 \mathrm{~d}$ after calving $(5.5 \%)$ but by d 33 this had declined to $1.5 \%$. The current study agrees with the latter observation in that pre- $(\mathrm{d}-18)$ and postcalving (d 36) did not differ in the potential contribution of alanine to gluconeogenesis (5.9 and $4.6 \%$, respectively). In contrast to the hypothesis of Reynolds et al. (2003), however, direct measures of removal of glucogenic AA by the liver were similar pre- and postcalving ( 82 and 80 mmol of glucose equivalents per $\mathrm{h}$, respectively), with maximal potential contributions of 15.7 versus $11.9 \%$, in the pre- and postcalving periods, respectively. These estimates are maximal contributions because part of the hepatic removal of AA is used for the synthesis of export proteins; for example, up to $20 \%$ of liver Phe removal is used for this purpose (Raggio et al., 2007). 
Two possible explanations may account for the differences observed between the results of Reynolds et al. (2003) and the current study. First, the current study offered $50 \%$ more energy precalving, whereas the cows received a similar amount of energy postcalving compared with the latter study. Second, the ration used in the current study contains a higher proportion of corn grain, which may have increased absorption of propionate, thus reducing the need for other glucogenic substrates.

Lactate. From the precalving to the postcalving period, lactate release by the PDV increased by 101 $\mathrm{mmol} / \mathrm{h}(P=0.01)$, whereas hepatic removal increased by $177 \mathrm{mmol} / \mathrm{h}(P=0.002$; Table 5$)$. If all the lactate extracted by the liver was used for gluconeogenesis, this would contribute $88 \mathrm{mmol} / \mathrm{h}$, or $60 \%$, to the observed increment in hepatic glucose net flux. Net portal absorption of lactate represented $57 \%$ of liver removal, and net hepatic removal in excess of the increased portal net absorption may not represent a net input of carbon (and glucose) to the animal, but rather reflects the dynamic exchange between glucose and lactate within the Cori cycle. Sources such as alanine deamination in muscle may also contribute to the post-hepatic lactate supply. Net flows of other glucose precursors, such as propionate (from increased energy intake) and glycerol (derived from net lipolysis), were not measured, but would be anticipated to increase gluconeogenesis.

Oxygen. Net splanchnic removal of $\mathrm{O}_{2}$ increased by $38 \%$ from d 18 precalving to d 36 postcalving $(P=$ 0.02 ), with two-thirds of this additional removal due to liver metabolism (Table 5). The increase in hepatic $\mathrm{O}_{2}$ removal was similar to that of hepatic blood flow $(43 \%)$. Although whole-body $\mathrm{O}_{2}$ consumption and energy intake are positively related, the increment in liver $\mathrm{O}_{2}$ removal was greater than the increment in $\mathrm{ME}$ intake. In addition to the increased splanchnic oxygen demands due to gluconeogenesis, digestion, and other metabolic processes associated with lactation, oxygen usage also increases because of proliferation of the splanchnic tissues in early lactation. For example, Gibb et al. (1992) reported that the gastrointestinal tract, liver, and spleen together increase in weight by $13.4 \%$ during the first $5 \mathrm{wk}$ postpartum.

\section{CONCLUSIONS}

The greater DMI of early lactation cows versus late gestation cows resulted in an increase in splanchnic release of AA, glucose, and urea. Despite the increased net portal appearance of AA, net liver AA removal did not increase. This confirms that net portal appearance of AA was not a regulating factor for liver AA removal. This also means that the potential contribution of AA to gluconeogenesis did not increase from pre- to postcalving, although glucose liver net flux increased over that period. Together, these data indicate that in early lactation for cows consuming these diets and producing milk components at the rates measured here, metabolic priority is given to direct AA toward milk protein production rather than gluconeogenesis. Finally, the increase in net splanchnic release of glucose between pre- and postcalving only met half of the requirement for lactose output and therefore other metabolic fates of glucose (e.g., oxidation) must have declined.

\section{ACKNOWLEDGMENTS}

The authors thank the staff of the Lennoxville Dairy and Swine Research Centre for taking care of the animals and V. Dostie, M. Dupuis, M. Léonard, J. Renaud, and B. Vallerand of the Lennoxville Dairy and Swine Research Centre for their dedicated technical support. The authors also acknowledge the financial support of Dairy Farmers of Canada, the Natural Sciences and Engineering Research Council of Canada, and Agriculture and Agri-Food Canada (Lennoxville research contribution number 997). Part of these studies was funded by the Scottish Government Rural and Environment Research and Analysis Directorate (RERAD) within the core budget given to the Rowett Institute of Nutrition and Health, University of Aberdeen.

\section{REFERENCES}

AOAC. 1996. Official Methods of Analysis. 16th ed. Association of Official Analytical Chemists, Arlington, VA.

Bartels, H., and H. Harms. 1959. Sauerstoffdissoziationskurven des blutes von saügetieren. Pflugers Arch. 268:S334-S365.

Bauman, D. E., C. J. Peel, W. D. Steinhour, P. J. Reynolds, H. F. Tyrrell, A. C. G. Brown, and G. L. Haaland. 1988. Effect of bovine somatotropin on metabolism of lactating dairy cows: Influence on rates of irreversible loss ad oxidation of glucose and nonesterified fatty acids. J. Nutr. 118:1031-1040.

Bell, A. W. 1995. Regulation of organic nutrient metabolism during transition from late pregnancy to early lactation. J. Anim. Sci. 73:2804-2819.

Bennink, M. R., R. W. Mellenberg, R. A. Frobish, and D. E. Bauman. 1972. Glucose oxidation and entry rate as affected by the initiation of lactation. J. Dairy Sci. 55(Suppl. 1):712.

Benson, J. A., C. K. Reynolds, P. C. Aikman, B. Lupoli, and B. E. Beever. 2002. Effects of abomasal long chain fatty acid infusion on splanchnic nutrient metabolism in lactating dairy cows. J. Dairy Sci. 85:1804-1814.

Bergmeyer, H. U., and H. A. Beutler. 1985. Ammonia. Pages 454461 in Method in Enzymatic Analysis, 3rd ed. Vol. VIII. H. U. Bergmeyer, J. Bergmeyer, and M. Grassl, ed. Verlag Chemie, Deerfield Beach, FL.

Berthiaume, R., M. C. Thivierge, G. E. Lobley, P. Dubreuil, M. Babkine, and H. Lapierre. 2002. Effect of a jugular infusion of essential amino acids on splanchnic metabolism in dairy cows fed a protein deficient diet. J. Dairy Sci. 85(Suppl. 1):72-73. (Abstr.)

Borucki Castro, S. I., L. E. Phillip, H. Lapierre, P. W. Jardon, and R. Berthiaume. 2007. Ruminal degradability and intestinal digestibility of protein and amino acids in treated soybean meal products. J. Dairy Sci. 90:810-822. 
Calder, A. G., K. E. Garden, S. E. Anderson, and G. E. Lobley. 1999. Quantitation of blood and plasma amino acids using isotope dilution electron impact gas chromatography/mass spectrometry with U-13C amino acids as internal standards . Rapid Commun. Mass Spectrom. 13:2080-2083.

Canadian Council on Animal Care. 1993. Guide to the Care and Use of Experimental Animals. Vol. 1. 2nd ed. E. D. Olfert, B. M. Cross and A. A. McWilliam, ed. CCAC, Ottawa, ON, Canada.

Cant, J. P., E. J. DePeters, and R. L. Baldwin. 1993. Mammary amino acid utilization in dairy cows fed fat and its relationship to milk protein depression. J. Dairy Sci. 76:762-774.

Clark, J. H., H. R. Spires, R. G. Derrig, and M. R. Bennink. 1977. Milk production, nitrogen utilization and glucose synthesis in lactating cows infused postruminally with sodium caseinate and glucose. J. Nutr. 107:631-644.

Danfaer, A., V. Tetens, and N. Agergaard. 1995. Review and an experimental study on the physiological and quantitative aspects of gluconeogenesis in lactating ruminants. Comp. Biochem. Physiol. 111:201-210.

Doepel, L., H. Lapierre, and J. J. Kennelly. 2002. Peripartum performance and metabolism of dairy cows in response to prepartum energy and protein intake. J. Dairy Sci. 85:2315-2334.

Doepel, L., M. Lessard, N. Gagnon, G. E. Lobley, J. F. Bernier, P. Dubreuil, and H. Lapierre. 2006. Effect of glutamine supplementation on immune response and milk production in dairy cows. J. Dairy Sci. 89:3107-3121.

Doepel, L., G. E. Lobley, J. F. Bernier, P. Dubreuil, and H. Lapierre. 2007. Effect of glutamine supplementation on splanchnic metabolism in lactating dairy cows. J. Dairy Sci. 90:4325-4333.

Doepel, L., D. Pacheco, J. J. Kennelly, M. D. Hanigan, I. F. López, and H. Lapierre. 2004. Milk protein synthesis as a function of amino acid supply. J. Dairy Sci. 87:1279-1297.

Drackley, J. K. 1999. Biology of dairy cows during the transition period: the final frontier. J. Dairy Sci. 82:2259-2273.

Drackley, J. K., T. R. Overton, and G. N. Douglas. 2001. Adaptations of glucose and long-chain fatty acid metabolism in liver of dairy cows during the periparturient period. J. Dairy Sci. 84(E Suppl.):E100-E112.

Eisemann, J. H., G. B. Huntington, and C. L. Ferrell. 1987. Blood flow to hindquarters of steers measured by transit time ultrasound and indicator dilution. J. Dairy Sci. 70:1385-1390.

Gerloff, B. J., T. H. Herdt, W. W. Wells, J. S. Liesman, and R. S. Emery. 1986. Inositol and hepatic lipidosis. 1. Effect of inositol supplementation and time from parturition on liver and serum lipids in dairy cattle. J. Anim. Sci. 62:1682-1692.

Gibb, M. J., W. E. Ivings, M. S. Dhanoa, and J. D. Sutton. 1992. Changes in body components of autumn-calving Holstein-Friesian cows over the first 29 weeks of lactation. Anim. Prod. 55:339360.

Guinard, J., and H. Rulquin. 1994. Effect of graded levels of duodenal infusions of casein on mammary uptake in lactating cows. 2. Individual amino acids. J. Dairy Sci. 77:3304-3315.

Hanigan, M. D. 2005. Quantitative aspects of splanchnic metabolism in the ruminant. Anim. Prod. 80:23-32.

Heger, J., P. Patráš, S. Nitrayová, P. Dolešová, and A. Sommer. 2007. Histidine maintenance requirement and efficiency of its utilization in young pigs. Arch. Anim. Nutr. 61:179-188.

Huntington, G. B. 1990. Energy metabolism in the digestive tract and liver of cattle: influence of physiological state and nutrition. Reprod. Nutr. Dev. 30:35-47.

Huntington, G. B., C. K. Reynolds, and B. H. Stroud. 1989. Techniques for measuring blood flow in splanchnic tissues of cattle. J. Dairy Sci. 72:1583-1595.

Katz, M. L., and E. N. Bergman. 1969. Simultaneous measurements of hepatic and portal venous blood flow in the sheep and dog. Am. J. Physiol. 216:946-952

Koprowski, J. A., and H. A. Tucker. 1973. Bovine serum growth hormone, corticoids and insulin during lactation. Endocrinology 93:645-651.

Kunz, P. L., J. W. Blum, I. C. Hart, H. Bickel, and J. Landis. 1985. Effects of different energy intakes before and after calving on food intake, performance and blood hormones and metabolites in dairy cows. Anim. Prod. 40:219-231.

Lapierre, H., R. Berthiaume, G. Raggio, M. C. Thivierge, L. Doepel, D. Pacheco, P. Dubreuil, and G. E. Lobley. 2005. The route of absorbed nitrogen into milk protein. Anim. Sci. 80:11-22.

Lemosquet, S., G. Raggio, H. Lapierre, J. Guinard-Flament, and H. Rulquin. 2007. Effects of protein supply on whole body glucose rate of appearance and mammary gland metabolism of energy nutrients in ruminants. Pages 581-582 in Energy and Protein Metabolism and Nutrition. EAAP publication no. 124. I Ortigues-Marty, ed. EAAP, Rome, Italy.

Lescoat, P., D. Sauvant, and A. Danfaer. 1996. Quantitative aspects of blood and amino acid flows in cattle. Reprod. Nutr. Dev. 36:137174

Lobley, G. E., and H. Lapierre. 2003. Post-absorptive metabolism of amino acids. Pages 737-753 in Progress in Research on Energy and Protein Metabolism. W. B. Souffrant and C. C. Metges, ed. EAAP Publication No. 109. Wageningen Academic Publishers, Wageningen, the Netherlands.

Meijer, G. A. L., J. Van der Meulen, J. G. M. Bakker, C. J. Van der Koelen, and A. M. Van Vuuren. 1995. Free amino acids in plasma and muscle of high yielding dairy cows in early lactation. J. Dairy Sci. 78:1131-1141.

Milano, G. D., A. Hotston-Moore, and G. E. Lobley. 2000. Influence of hepatic ammonia removal on ureagenesis, amino acid utilization and energy metabolism in the ovine liver. Br. J. Nutr. 83:307315.

NRC. 2001. Nutrient Requirements of Dairy Cattle. 7th rev. ed. Natl. Acad. Sci., Washington, DC

Overton, T. R. 1998. Substrate utilization for hepatic gluconeogenesis in the transition dairy cow. Pages 237-246 in Proc. Cornell Nutrition Conference for Feed Manufacturers. Rochester, NY.

Overton, T. R., J. K. Drackley, C. J. Ottemann-Abbamonte, A. D. Beaulieu, L. S. Emmert, and J. H. Clark. 1999. Substrate utilization for hepatic gluconeogenesis is altered by increased glucose demand in ruminants. J. Anim. Sci. 77:1940-1951.

Overton, T. R., and M. R. Waldron. 2004. Nutritional management of transition dairy cows: Strategies to optimize metabolic health. J. Dairy Sci. 87(E Suppl.):E105-E119.

Raggio, G., S. Lemosquet, G. E. Lobley, H. Rulquin, and H. Lapierre. 2006. Effect of casein and propionate supply on mammary protein metabolism in lactating dairy cows. J. Dairy Sci. 89:4340-4351.

Raggio, G., G. E. Lobley, R. Berthiaume, D. Pellerin, G. Allard, P. Dubreuil, and H. Lapierre. 2007. Effect of protein supply on hepatic synthesis of plasma and constitutive proteins in lactating dairy cows. J. Dairy Sci. 90:352-359.

Raggio, G., D. Pacheco, R. Berthiaume, G. E. Lobley, D. Pellerin, G. Allard, P. Dubreuil, and H. Lapierre. 2004. Effect of level of metabolizable protein on splanchnic flux of amino acids in lactating dairy cows. J. Dairy Sci. 87:3461-3472.

Reynolds, C. K., P. C. Aikman, B. Lupoli, D. J. Humphries, and D. E. Beever. 2003. Splanchnic metabolism of dairy cows during the transition from late gestation through early lactation. J. Dairy Sci. 86:1201-1217.

Reynolds, C. K., H. Lapierre, H. F. Tyrrell, T. H. Elsasser, R. C. Staples, P. Gaudreau, and P. Brazeau. 1992. Effects of growth hormone-releasing factor and intake on energy metabolism in growing beef steers: Net nutrient metabolism by portal-drained viscera and liver. J. Anim. Sci. 70:752-763.

SAS Institute. 1999. SAS System for Mixed Models. SAS Institute Inc., Cary, NC.

Swaisgood, H. E. 1995. Protein and amino acid composition of bovine milk. Pages 464-468 in Handbook of Milk Composition. R. G. Jensen, ed. Academic Press, Toronto, ON, Canada.

VandeHaar, M. J., G. Yousif, B. K. Sharma, T. H. Herdt, R. S. Emery, M. S. Allen, and J. S. Liesman. 1999. Effect of energy and protein density of prepartum diets on fat and protein metabolism of dairy cattle in the periparturient period. J. Dairy Sci. 82:1282-1295.

Wieghart, M., R. Slepetis, J. M. Elliot, and D. F. Smith. 1986. Glucose absorption and hepatic gluconeogenesis in dairy cows fed diets varying in forage content. J. Nutr. 116:839-850. 